\title{
Sustainable development goals for the coastal territories of the Baltic Sea Region
}

\author{
Yulia Farafonova, Inobbat Alieva, Andrei Golubev, Svetlana Shchekoturova,and Marina \\ Tishchuk \\ Immanuel Kant Baltic Federal University, Gorky, 23, 236029 Kaliningrad, Russia
}

\begin{abstract}
The article focuses on determining priority Sustainable Development Goals (SDGs) for the mesolevel coastal territories of the Baltic Sea Region (BSR), including EU and Russian ones. The analysis of strategic documents and supranational (BSR), national and subnational voluntary reviews allows identifying the main approaches to the development of strategies and the selection of indicators for monitoring progress towards the achievement of the SDGs. The paper identifies priority areas and objectives for designing sustainable development strategies in the BSR coastal territories. As a tool to choose the development path to sustainability in three spheres (economic, social and environmental), the authors propose to conduct a mesolevel economic complexity analysis.
\end{abstract}

\section{Introduction}

In 1987, "Our Common Future", the Brundtland Commission's report, [1] was published defining sustainable development as the development that meets the current needs of people without compromising the ability to meet the needs of future generations. In 2015, the UN adopted 17 Sustainable Development Goals (SDGs), which countries aim to achieve by 2030 [2]. The goals are not legally binding, despite that, countries and supranational associations commit to integrating them into their development strategies. This is true for all the countries of the Baltic Sea Region (BSR), for which, in 2009 the European Commission [3] developed a special macroregional strategy [4]. This strategy was brought in line with the SDGs, as were the strategies of the individual EU member states of the BSR and the national development goals of Russia.

Recognizing the importance of the SDGs, countries tailor them to their priority needs and objectives. National strategies can also include other goals which are of maximum relevance for the country, taking into account its current economic, social and environmental situation.

At the same time, the SDGs incorporation into subnational strategies is currently an exception rather than a rule, while the OECD states that most of the targets set by the UN to achieve the SDGs cannot be met without the close involvement of regional and local authorities [5]. Thus, the task of localizing the SDGs for the coastal territories of the BSR is of undoubted relevance. 


\section{Materials and methods}

To determine the priority goals for the coastal territories of the BSR, the paper analyzes statistical data characterizing the level of their socio-economic development, supranational, national and subnational strategic documents, as well as voluntary national reviews of the countries and territories of the Baltic Sea Region presented on the UN website [6] containing indicators for the SDGs achievement level.

\section{Results and discussion}

\subsection{National strategic documents}

The first sustainable development documents in the BSR were adopted after the United Nations 1992 Conference on Environment and Development held in Rio de Janeiro, Brazil. These include Sweden's 1994 Strategy for Sustainable Development, Estonia's 1995 Sustainable Development Act, Russia's 1996 Concept for the Transition of the Russian Federation to Sustainable Development.

The next milestone was the UN World Summit on Sustainable Development "RIO + 10" held in 2002 in Johannesburg. Following it, in 2002-2005, national sustainable strategies were developed in Germany, Latvia, Sweden, Lithuania, Estonia.

In 2006, the EU updated its 2001 sustainable development strategy [7]. To harmonize the national strategy with this new document, in 2010 the Parliament of Latvia adopted the Strategy for Sustainable Development of Latvia until 2030 (Latvia 2030) [8]. Lithuania also updated the National Sustainable Development Strategy in 2009 revising it again in 2011 [9]. Sweden changed its national sustainable development strategy in 2004 and 2006.

Later, national strategies were revised to ensure their consistency with the 2030 Agenda and the SDGs. In 2017, Germany adopted the updated Strategy for Sustainable Development of Germany (Deutsche Nachhaltigkeitsstrategie - DNS) [10] containing national indicators for achieving the SDGs. In March 2021, the government decided that there is a need for another revision of the national strategy. In Poland, the 2030 Agenda and the Sustainable Development Goals were incorporated into the Strategy for Responsible Development (SRD) adopted by the Council of Ministers in February 2017 [11]. In Denmark, with its sustainable development strategy adopted in 2014 [12], in 2017 the government developed and adopted the Action Plan on the implementation of the UN Global SDGs [13]. In Latvia, the achievement of the country's SDGs until 2030 is the main objective of its 7-year national development plans [14]. In Finland, the government and parliament hold a regular dialogue on the implementation of the 2030 Agenda, while the National Audit Office has incorporated it into its audit programs. The sustainability assessment has been integrated into the government's annual policy planning, budgeting and reporting cycle. Some ministries have adopted the 2030 Agenda as the guidelines for their strategies. In 2020, Estonia adopted the development strategy "Estonia 2035" [15] incorporating the SDGs, in addition, all its strategic documents shall be checked to estimate the impact of the measures and actions specified in them on the natural, social, economic and cultural environment. All strategic development plans should be developed taking into account the SDGs [16].

In Russia, 12 national projects and the Comprehensive Plan for the Modernization and Expansion of Backbone Infrastructure directly or indirectly integrated 107 of the 169 tasks identified to achieve the UN SDGs [17]. The national development goals of the Russian Federation until 2030 adopted in June 2020 [18] also largely correspond to the UN goals. For instance, "preservation of the population, health and well-being of people" correlates with Goals 1 and 3; "comfortable and safe environment" - Goals 3, 6, 9, 12, 13, 14; "conditions 
for self-fulfilment and the unlocking of talent" - Goals 4, 9, 11, "decent, efficient work and successful entrepreneurship" - Goal 8, 9; "digital transformation" - Goal 9. At the same time, there is no mentioning of Goals $7,10,12,15,16,17$. The country's national projects are being revised to integrate national development goals. There are also other strategic documents directly affecting the achievement of sustainable development objectives. These include the Food Security Doctrine of the Russian Federation [19], the Education Development [20], Accessible Environment [21], Employment Promotion [22], Comprehensive Rural Development [23] state programmes.

\subsection{Monitoring the achievement of sustainable development goals}

All the BSR countries submit voluntary reviews on the achievement of sustainable development goals [24]. It should be noted that in addition to the indicators developed by the $\mathrm{UN}$, the countries also use national indicators that most accurately reflect progress in the areas of the highest national significance.

For example, Denmark has already achieved several SDGs [25], but the country has proposed some new indicators for each SDG complementing and clarifying the UN ones [26]. These indicators were developed with the participation of the general public. Citizens, companies, organizations, scientific and educational institutions, government authorities made more than 6,000 proposals, of which 197 indicators were selected. In Poland, data on global indicators are also complemented by national indicators for each SDG. In Germany, every 2 years the government prepares a report on the National Sustainable Development Strategy, which includes the national SDG indicators. Sweden reports data on $153 \mathrm{UN}$ indicators, which the country considers relevant (73\%) not only nationally but also globally supplementing them with national indicators, most of which are unique, some complement global ones, and some are proxies that replace the global ones with statistical data available in the country. In its 2018 review, Latvia presented data on the indicators of the UN SDGs, Eurostat, the Sustainable Development Strategy of Latvia until 2020 and the National Development Plan of Latvia 2014-2020, all of which can be used to monitor the achievement of the UN SDGs.

However, some countries use only the UN indicators to monitor their SDGs progress. For instance, Finland presents national data on 161 global SDG indicators, for most of them from 1990 onwards. Lithuania publishes a report on 148 UN SDG indicators relevant to the country on the Official Statistics Portal [27]. In 2017, Estonia aligned its list of sustainable development indicators with the SDGs. Russia, which presented its first voluntary review in 2020, also monitors its progress exclusively by the UN indicators.

The analysis of the Sustainable Development Report [28] shows that most of the BSR countries are experiencing difficulties in reaching Goals 10, 13 and 14 (there is no data for Goal 12), although their progress towards achieving the SDGs is uneven. This unevenness becomes even more pronounced at the subnational level, as will be shown below. To even out the situation, the countries of the region need to develop and implement sustainable development strategies for individual territories (especially those lagging behind).

\subsection{Subnational sustainable development strategies}

Achieving the SDGs nationally does not exclude the possibility that some regions of the country may experience significant problems in the transition to sustainable development (see, for example, data [29]). This is often the case for the coastal territories of the BSR, where the level of socio-economic development is usually lower than the national average (Tab. 1). 
Table 1. GRP per capita (PPP) in the coastal territories of the Baltic Sea region, 2009-2018, USD.

\begin{tabular}{|c|c|c|c|c|c|c|c|c|c|c|}
\hline & 2009 & 2010 & 2011 & 2012 & 2013 & 2014 & 2015 & 2016 & 2017 & 2018 \\
\hline Danmark & 39,201 & 41,682 & 42,809 & 43,236 & 45,377 & 46,769 & 48,365 & 51,322 & 54,407 & 56,552 \\
\hline Hovedstaden & 19,609 & 54,256 & 54,538 & 55,548 & 58,663 & 60,980 & 63,831 & 66,785 & 70,877 & 73,519 \\
\hline Zealand & 27,521 & 29,389 & 30,151 & 30,680 & 31,628 & 32,270 & 34,200 & 35,463 & 37,490 & 39,350 \\
\hline \begin{tabular}{|l} 
Southern \\
Denmark
\end{tabular} & $\beta 6,390$ & 38,475 & 40,113 & 40,184 & 42,310 & 43,486 & 44,428 & 46,871 & 49,388 & 51,622 \\
\hline Estonia & 20,580 & 21,773 & 24,720 & 26,144 & 27,619 & 29,102 & 29,468 & 31,223 & 33,843 & 36,416 \\
\hline Finland & $\beta 7,993$ & 38,977 & 40,920 & 40,895 & 41,509 & 41,760 & 42,505 & 44,922 & 47,498 & 49537 \\
\hline Western Finland & $\beta 3,957$ & 34,977 & 37,282 & 37,236 & 37,140 & 37,382 & 37,895 & 39,704 & 41,801 & 43,851 \\
\hline Helsinki area & 52,036 & 53,230 & 54,158 & 53,506 & 55,037 & 54,712 & 56,404 & 59,183 & 62,031 & 63,926 \\
\hline $\begin{array}{l}\text { Northern and } \\
\text { Eastern Finland }\end{array}$ & 29,867 & 31,301 & 33,272 & 33,465 & 34,064 & 34,588 & 34,612 & 37,179 & 39,492 & 41,613 \\
\hline Åland & 16,672 & 46,050 & 47,355 & 50,662 & 51,927 & 50,890 & 52,743 & 53,363 & 54,866 & 53,744 \\
\hline Germany & $\beta 7,516$ & 39,679 & 42,527 & 43,373 & 44,981 & 47,007 & 47,678 & 50,543 & 53,052 & 54,439 \\
\hline $\begin{array}{l}\text { Mecklenburg- } \\
\text { Vorpommern } \\
\end{array}$ & 25,641 & 26,757 & 28,515 & 29,051 & 30,558 & 32,087 & 32,215 & 33,888 & 36,387 & 37,250 \\
\hline $\begin{array}{l}\text { Schleswig- } \\
\text { Holstein }\end{array}$ & $\beta 1,644$ & 32,656 & 34,584 & 36,017 & 37,178 & 38,623 & 38,717 & 40,987 & 43,369 & 44,732 \\
\hline Latvia & 6,820 & 17,416 & 19,652 & 21,442 & 22,718 & 23,782 & 24,818 & 26,349 & 28,483 & 30,717 \\
\hline Lithuania & 8,157 & 20,057 & 22,820 & 24,627 & 26,701 & 28,132 & 28,807 & 30,959 & 33,811 & 35,825 \\
\hline $\begin{array}{l}\text { Central and } \\
\text { Western } \\
\text { Lithuania } \\
\end{array}$ & 5,116 & 16,752 & 19,289 & 20,697 & 22,200 & 23,275 & 23,758 & 25,520 & 28,040 & 29,314 \\
\hline Poland & 9,099 & 20,800 & 22,581 & 23,544 & 24,423 & 25,300 & 26,524 & 27,948 & 29,808 & 31,394 \\
\hline $\begin{array}{l}\text { West Pomeranian } \\
\text { Voivodeship }\end{array}$ & 6,663 & 17,759 & 18,931 & 19,731 & 20,344 & 21,204 & 22,428 & 23,424 & 24,842 & 26,055 \\
\hline $\begin{array}{l}\text { Warmia and } \\
\text { Mazury } \\
\text { Voivodeship } \\
\end{array}$ & 4,060 & 15,077 & 16,244 & 16,832 & 17,467 & 18,084 & 18,802 & 19,927 & 20,903 & 21,575 \\
\hline $\begin{array}{l}\text { Pomeranian } \\
\text { Voivodeship }\end{array}$ & 8,790 & 19,962 & 21,682 & 23,018 & 23,527 & 24,090 & 25,498 & 27,072 & 28,786 & 30,500 \\
\hline \begin{tabular}{|l} 
Russian \\
Federation \\
\end{tabular} & 15,992 & 16,676 & 18,305 & 18,886 & 19,412 & 19,279 & 19,039 & 19,510 & 21,180 & 23,361 \\
\hline $\begin{array}{l}\text { Kaliningrad } \\
\text { Region }\end{array}$ & 2,899 & 13,159 & 14,714 & 15,119 & 14,813 & 15,472 & 15,247 & 16,236 & 17,518 & 18,632 \\
\hline Leningrad region & 8,042 & 18,105 & 19,428 & 20,892 & 19,884 & 18,912 & 20,267 & 21,215 & 22,228 & 24,350 \\
\hline St Petersburg & 1,863 & 22,075 & 24,481 & 24,752 & 25,253 & 24,533 & 27,570 & 28,841 & 29,910 & 31,534 \\
\hline Sverige & 10,188 & 42,209 & 44,504 & 45,303 & 46,137 & 47,046 & 48,975 & 50,437 & 52,696 & 53,806 \\
\hline Stockholm & 57,899 & 58,565 & 62,415 & 63,563 & 64,348 & 66,238 & 69,148 & 70,087 & 71,748 & 72,760 \\
\hline $\begin{array}{l}\text { East Central } \\
\text { Sweden } \\
\end{array}$ & $\beta 4,655$ & 36,625 & 38,732 & 39,652 & 40,267 & 40,531 & 41,768 & 43,370 & 45,804 & 46,836 \\
\hline $\begin{array}{l}\text { Småland with } \\
\text { islands }\end{array}$ & $\beta 3,478$ & 35,519 & 37,876 & 38,402 & 39,314 & 39,699 & 41,465 & 43,560 & 46,149 & 47,111 \\
\hline Southern Sweden & $\beta 4,510$ & 36,216 & 37,498 & 38,192 & 39,112 & 40,092 & 41,839 & 42,495 & 44,935 & 45,752 \\
\hline $\begin{array}{l}\begin{array}{l}\text { Northern Middle } \\
\text { Sweden }\end{array} \\
\end{array}$ & 32,602 & 34,792 & 36,171 & 37,103 & 37,488 & 37,901 & 38,914 & 40,405 & 42,192 & 43,647 \\
\hline Middle Norrland & $\beta 6,088$ & 39,031 & 39,567 & 40,153 & 40,366 & 40,724 & 41,396 & 42,654 & 45,010 & 46,533 \\
\hline
\end{tabular}

Source: authors' calculations based on data from Rosstat [30,31], Eurostat [32], OECD [33]. 
Table 2 shows that the level of per capita GRP in the coastal territories of the BSR, as a rule (with a few exceptions), is significantly lower than the average in the corresponding country. Sustainable development involves an increase in the level of socio-economic development of most of the coastal territories.

The governments of virtually all the BSR countries recognize the importance of acting at the subnational level announcing it in their national sustainable development strategies. However, there are few practical examples of the implementation of these programme statements. In Sweden and Finland, individual municipalities and cities, for instance, Helsinki [34,35] and Turku [36], use the UN SDGs in their strategies and submit their voluntary reviews. The South Denmark Strategy 2020-2024 involves the achievement of the SDGs at the regional level [37,38]. In Germany, the state government of Schleswig-Holstein has coordinated its regional strategy with the SDGs. The updated document identifies 8 key areas of action and 75 indicators presented in the 2020 report [39]. Mecklenburg-Western Pomerania is to present its sustainable development strategy in 2021.

The sustainable strategies for the coastal territories should be designed taking into account regional specifics as its development is largely determined by its unique resources [40,41], which include the location that in the case of the coastal territories creates the conditions for the blue economy development $[42,43]$. This means that a sustainable development strategy for a coastal territory of the BSR shall particularly focus on Goals 8, 9, 11, 13 and 14, which are closely intertwined with the EU BSR strategy's orientation to the development of sectors and industries related to the use of marine resources. [44-46]. Goals 10, 13 and 14 should also be a priority for the BSR countries since progress on them is the least.

When determining the key industries, the development of which can contribute to the sustainable development of a territory, it is also advisable to focus on the strategic areas identified by the economic complexity analysis [47-50]. In the BSR, such an analysis was carried out, for example, for the Kaliningrad region for the period 2015-2017 [51]. It indicated the need for specific changes in the structure of the economy, an active industrial policy aimed at enhancing the international competitiveness of the producers of specific goods in the region's export portfolio that meet the requirements of reducing the level of resource consumption while creating value, as well as increasing the welfare in the region. It also showed the need to develop services related to these product categories. The EC analysis for 2017-2019 confirmed these findings.

\section{Conclusions}

1. The coordination of national strategies with the SDGs has been completed in all the BSR countries, and their achievement is carefully monitored.

2. For the primary objectives, countries introduce their own indicators and even separate national goals. Indicators also are developed if the goal set by the UN has already been achieved but there are still unresolved national issues.

3. At the mesolevel, coordination of strategies and tracking of progress in achieving the SDGs in the BSR is practically non-existent. It is done mostly at the level of municipalities, however, for example in Russia, the territories of the meso-level have greater authority and municipal goals should comply with the regional ones.

4. The practice of developing sustainable development strategies for the coastal territories in line with the country's priority SDGs should be expanded.

5. As the SDGs should reflect the specifics of the coastal territories, it is impossible to formulate sustainable goals and objectives not coordinating them with UN Goal 14 and the objectives for the development of the blue economy in the BSR.

6. When defining strategic priorities for sustainable development of a coastal territory to identify areas in which additional efforts are required, it is necessary to monitor 
the progress towards the achievement of the SDGs. In the absence of statistical data, it is recommended to develop proxy indicators or use indicators proposed by the countries.

7. The ways for overcoming the challenges to the SDGs achievement (priority areas for industrial development) can be identified through the economic complexity analysis at the subnational level.

\section{Acknowledgements}

The study was carried out with the financial support of the RFBR and the Government of the Kaliningrad Region within the framework of the scientific project No. 19-410-390002 "Economic complexity and sector-specific strategy selection by the regions of Russia in the context of the emerging value creation paradigm, using the case of the Kaliningrad region".

\section{References}

1. Report of the World Commission on Environment and Development: Our Common Future (1987)

2. Transforming our world: The 2030 Agenda for Sustainable Development. Resolution adopted by the UN General Assembly on September 25, 2015 No. A / RES / 70/1

3. European Commission. EU Approach to sustainable development, https://ec.europa.eu/

4. EU Strategy for the Baltic Sea Region, https://www.balticsea-region-strategy.eu/

5. OECD, A Territorial Approach to the Sustainable Development Goals: Synthesis report. 2020, https://www.oecd-ilibrary.org/

6. Voluntary National Reviews, https://sustainabledevelopment.un.org/

7. Renewed EU Sustainable Development Strategy, https://data.consilium.europa.eu/

8. Sustainable Development Strategy of Latvia until 2030, https://www.pkc.gov.lv/

9. National Strategy for Sustainable Development. Lithuania 2011, https://am.lrv.lt/

10. German Sustainable Development Strategy

11. Information on the Strategy for Responsible Development, https://www.gov.pl/

12. Danish Strategy for Sustainable Development, https://eng.mst.dk/

13. Action plan for the UN \& \# 39 ; g global goals - Denmark's follow-up of the UN \& \# 39 ;s global goals for sustainable development, https://www.regeringen.dk

14. National Development Plan Latvia, https://www.pkc.gov.lv/

15. Estonia 2035, https://valitsus.ee/ru/

16. Sustainable Estonia 21, https://www.envir.ee/

17. Forbes: Sustainable Development in Russia: History, Companies and Facts, https://www.forbes.ru/

18. On the national development goals of the Russian Federation for the period up to 2030. Decree of the President of the Russian Federation of July 21, 2020 No. 474

19. Decree of the President of the Russian Federation of January 21, 2020 No. 20 "On approval of the Doctrine of food security of the Russian Federation"

20. Resolution of the Government of the Russian Federation of December 26, 2017 N 1642 (as amended on March 15,2021) \&quot; On approval of the state program of the Russian Federation\&quot; Development of education \&quot 
21. Resolution of the Government of the Russian Federation of March 29, 2019 No. 363 \&quot;On approval of the state program of the Russian Federation\&quot; Accessible Environment \&quot

22. Decree of the Government of the Russian Federation of April 15, 2014 N 298 (as amended on March 29, 2021) \&quot; On approval of the state program of the Russian Federation\&quot; Promotion of employment of the population \&quot

23. Decree of the Government of the Russian Federation of 05/31/2019 N 696 (as amended on 03/31/2021) \&quot;On approval of the state program of the Russian Federation\&quot; Integrated development of rural areas \&quot; and on amendments to some acts of the Government of the Russian Federation\&quot

24. Sustainable Development Knowledge Platform: Voluntary National Reviews, https://sustainabledevelopment.un.org/

25. Statistics Denmark, https://www.dst.dk/en/

26. Make Global Goals Our Goals: 197 Danish indicators for a more sustainable world. 2020, Copenhagen: Statistics Denmark and the 2030-Panel

27. Voluntary National Review on the Implementation of the UN 2030 Agenda for Sustainable Development in Lithuania

28. Sustainable Development Report 2020, https://dashboards.sdgindex.org/

29. OECD, Measuring the distance to SDGs in regions and cities, https://www.oecd-localsdgs.org/

30. Rosstat, https://rosstat.gov.ru/

31. EMISS, Gross Regional Product Per Capita, https://fedstat.ru/

32. Eurostat, Euro, ECU exchange rates annual data, Gross domestic product (GDP) at current market prices by NUTS 3 regions, Average annual population to calculate regional GDP data (thousand persons) by NUTS 3 regions, https://ec.europa.eu/

33. OECD, Purchasing power parities (PPP) (indicator) (2020)

34. From Agenda to Action - The Implementation of the UN Sustainable Development Goals in Helsinki 2019, https://sdgs.un.org/

35. Local2030: Localizing the SDGs, https://www.local2030.org/

36. A Voluntary Local Review 2020, The implementation of the 2030 Agenda for Sustainable Development in the City of Turku, https://www.turku.fi/

37. Regiona Ludvikling Sstrategi 2020-2023: Fremtidens Syddanmark, https://ec.europa.eu/

38. OECD, \&quot, A territorial approach to the Sustainable Development Goals in Southern Denmark, Denmark\&quot (2020)

39. Schleswig-Holstein: Nachhaltige Entwicklung, https://www.schleswig-holstein.de/

40. O. Y. Voronkova, V. Yankovskaya, I. Kovaleva, I. Epishkin, I. Iusupova, Y. Berdova, Entrepreneurship and Sustainability Issues, 7(1), 662 (2019)

41. E3S Web Conf., Int. Conf. on Efficient Production and Processing (ICEPP-2020), 161 (2020)

42. Philipp, Robert, Prause, Gunnar and Meyer, Christopher, Transport and Telecommunication J., 21(1), 69 (2020)

43. E. Pudzis, et al., IOP Conf. Ser.: Earth Environ. Sci., 453012033 (2020)

44. A Sustainable Blue Growth Agenda for the Baltic Sea Region, https://www.balticsearegion-strategy.eu/ 
45. Revised Action Plan replacing the Action Plan of 17 March 2017, https://www.balticsearegion-strategy.eu/

46. European Commission. Oceans and Fisheries: Baltic Sea, https://ec.europa.eu/

47. F. Diogo, Falguera, P. S. Fernanda, E. B. Mariano, H. Dominik, Sustainability, 13(3), 1265 (2021)

48. B. Cakir, I. Schluep, P. Aerni, I. Cakir, Sustainability, 13(4), 2049 (2021)

49. C. C. Pérez-Hernández, B. C. Salazar-Hernández, J. Mendoza-Moheno, E. Cruz-Coria, M. A. Hernández-Calzada, Sustainability, 13(2), 945 (2021)

50. E. Bergamini, G. Zachmann, Sustainability, 13(1), 32 (2021)

51. G. Roos, K. Voloshenko, Yu. Drok, T. E. Farafonova, Yu. Yu. 2020, Balt. Reg., 12(1), 156 (2020) 